\title{
Non-Performing Assets in Public and Private Sector Banks in India (2008-2013) Mr. Bijender ${ }^{1}$
}

$\left({ }^{1}\right.$ Extension Lecturer in Govt. College, Safidon)

( ${ }^{1}$ boorabijender88@gmail.com)

\begin{abstract}
The study is based on the NPA value of public \& private banks in India. The value of nonperforming assets effects the reputation of a bank. NPAs reflect the performance of different banks. If a bank has a large number of nonperforming assets, it means that bank is not working well. The main purpose of this paper is to find out the actual value of NPA in India from 2008-13. It is clear the value of NPA in small industries and agriculture in India. The paper also shows the value of NPA in small scale industries and agriculture sector. The value of NPA is increasing in every year. NPA reflects the value of profit and show the level of management of every private sector and public sector banks in India. NPA has become the main problem for Indian economy. The high NPA value effect the bank's reputation and growth. As we know that the Indian banks are facing lot of financial problems but it is happen because of the high value of NPA. Most of the NPA value is coming from public sector banks in India that effect the profitability. So to improve the value of profitability the Banks will have to take some suitable steps.
\end{abstract}

Key Words: Public and private banks, economy, agriculture.

\section{INTRODUCTION}

The banking activities started in the $18^{\text {th }}$ century in India. Lot of private and public sector banks have started his work to provide the financial help to the needy peoples and business organisations. All the private and public sector banks have a huge network of branches in rural and urban areas in India. As we know that the private sector banks are those banks where the maximum part of his equity is held by private shareholders but not by the government. For example the ICICI bank, Axis bank etc [13]. But in other side the public sector banks are those banks where the maximum part of these banks is held by the government. For example the SBI, State Bank of Patiala, OBC etc. All the private and public sector banks have a lot of value of NPA in India. The value reflects the risk and profitability of a bank. The RBI has taken many steps to improve the conditions during the recommendations of Narsimham committee in 1992-93. The assets which installment due remains unpaid more than 90 days that will be counted under nonperforming assets. But if we define it in simple words than we can say that if the income is realized from the assets within 90 day that is counted underperforming assets but if it is overdue more than 90 days than it will be counted under nonperforming assets. The norms for identification of NPA adopted from the year ending $31^{\text {st }}$ march, 2004 [6] According to the security interest act, 2002 the banks can issue the notice to the defaulters to pay the dues within 60 days and if the borrower received the notice from the banks the financial institution cannot sale the secured assets without the consent of lenders. The main purpose of sending the notice to the defaulters so that if he does not pay the due amount within given period than the secured assets will be sold by the bank [1]. The NPA refers to a loan or an advance where:

$>$ If the interest and installment is overdue for a period of more than 90 days in respect of a term loan.

$>$ If the account is out of order for a period of more than 90 days, in respect of an Overdraft/Cash Credit.

$>$ The bill remains overdue for a period of more than 90 days in the case of bills purchased and discounted.

$>$ If any amount is remains overdue for a period of more than 90 days in respect of other accounts [7].

The Effect of NP: The high value of NPA affects the value of profit for any financial institution or bank. It is responsible in increasing the cost of capital and risk of the banks. Some point is given below to show the impact of NPA on the banks or financial Institutions in India:

$>$ It put the impact on earning capacity of assets. 
$>$ It is responsible in increasing in cost of capital.

$>$ It is responsible to decrease the value of share and put impact on the reputation of the banks in the capital market.

$>$ It affects the ability of risk of banks [8].

$>$ The owners do not get good return on their capital and if the banks fail to get its money then the owners lose their assets.

$>$ If the bank fails then the depositors cannot find a market on savings and he loses his balance. The banks receive the amount of loss after charging the higher interest rates.

$>$ The NPA put the impact on the current profits of banks [9].

\section{Factor responsible for rise in NPA}

$>$ Absence of regular industrial visit

$>$ Improper SWOT analysis.

$>$ Change in Govt. policies [4].

$>$ Business failures.

$>$ The RBI and NABARD banks did not give the proper support in collecting the funds of the banks.

$>$ More Corruption and nepotism is responsible for rising in NPA.

$>$ The proposal appraisal system is not good.

$>$ Inefficient of credit risk management.

$>$ Direct lending under subsidy schemes.

$>$ Provide the loans to that people and organisation which financial condition was not good.

$>$ The selection of borrowers is not good.

$>$ Delay in completing the project.

$>$ Very poor debt management by the borrower.

$>$ Time involved in the legal process and realization of securities [10].

\section{LITERATURE REVIEW}

Satpal, (2014) in his study he focus on the NPA of public and private sector banks in India. He also finds out the gross and net NPA of these banks. He defines the actual and correct definition of the nonperforming assets and the factors that are responsible for the high value of nonperforming assets.

Rao \& Patel, (2015) it is a study about the all types of banks in India such as public, private and foreign sector banks. The main purpose of the study is to find out interpret various NPA related ratios for aggregates of public sector, private sector and foreign banks in India from 2009 to 2013. Non-performing assets had been the single largest cause of frustration of the banking sector of India.

Balasubramaniam, (2001) this study tells about the NPA and the value of profit of commercial banks in India which is affected by some emerging issues such as the value of NPA. The objective of increase in the value of profit and reduce the value of NPA can be achieved by good credit appraisal procedures, effective internal control systems along with their efforts to improve asset quality in their balance sheets.

Kaur and Saddy, (2011) this paper shows the research on a comparative study of NPA in public and private sector banks in India and show the actual concept of NPA, what are the factors who affect the value of NPA. It is also known about the capital to risk weight age assets ratio of these banks, management of credit risk and measures to control the threat of NPAs are also discussed in the paper.

\section{OBJECTIVE OF THE STUDY}

The main objective of this study is to find out the value of NPA in private sector banks and public sector banks from 2008 to 2013 and find out the loan assets in public and private sector banks. What is the reason behind in increasing the value of NPA in different years? 


\section{RESEARCH METHODOLOGY}

The present study is based on the value of NPA of Indian Banks. Banking industries is taken for this study. The study is based on secondary data collected from the different research paper and internet sites. All the research paper has the different points and index which is shown in this paper.

\section{ANALYSIS AND INTERPRETATION}

\section{NPA Classification}

The nonperforming assets can be divided into three categories which is given below:

a) Substandard Assets: The assets which is considered as nonperforming assets for a period of 12 months or equal of 12 months.

b) Doubtful Assets: If the assets is remained in the sub standard category for 12 months that assets will be counted under doubtful assets from 31 march, 2005. A loan classified under the doubtful category has all the weakness characteristics as defined for the sub-standard assets; also it has added characteristics that the weakness makes full liquidation or collection, on the basis of the currently known conditions, facts, and values that are highly doubtful and questionable.

a) Loss Assets: A loss asset is one where loss has been identified by the bank's internal auditors and RBI's external auditors, but the amount has not been written off fully [2].

Table I Classification of Loan Assets of Public Sector Banks (In Crores)

\begin{tabular}{|l|l|l|l|l|l|l|}
\hline Bank /Year & \multicolumn{2}{|l|}{ Standard Advances } & \multicolumn{2}{l}{ Sub-Standard Advances } & \multicolumn{2}{l}{ Doubtful Advances } \\
& \multicolumn{2}{|l|}{} \\
\hline $\begin{array}{l}\text { Public Sector } \\
\text { Bank }\end{array}$ & Amount & $\begin{array}{l}\text { Percentage } \\
(\%)\end{array}$ & Amount & $\begin{array}{l}\text { Percentage } \\
(\%)\end{array}$ & Amount & $\begin{array}{l}\text { Percentage } \\
(\%)\end{array}$ \\
\hline 2008 & $\begin{array}{l}16564.5 \\
1\end{array}$ & 97.67 & 168.46 & 0.99 & 190.83 & 1.13 \\
\hline 2009 & $\begin{array}{l}20,546 . \\
01\end{array}$ & 97.90 & 195.21 & 0.93 & 207.08 & 0.99 \\
\hline 2010 & $\begin{array}{l}24,551 . \\
47\end{array}$ & 97.72 & 276.85 & 1.10 & 246.79 & 0.98 \\
\hline 2011 & $\begin{array}{l}29,888 . \\
72\end{array}$ & 97.68 & 336.12 & 1.10 & 319.55 & 1.04 \\
\hline 2012 & $\begin{array}{l}34,379 . \\
00\end{array}$ & 96.83 & 603.76 & 1.70 & 470.75 & 1.33 \\
\hline 2013 & $\begin{array}{l}38,999 . \\
85\end{array}$ & 96.16 & 765.89 & 1.89 & 734.85 & 1.81 \\
\hline
\end{tabular}

Source: (http://www.rbi.org.in/) [14]

In the table it is clear the loan assets of public sector bank in different years started from 2008. In this year the amounts of standard advances were Rs. 16564.51 Crores that is 97.67 of total advances but it increased Rs. 38999.85 Crores in 2013. Same as the sub-standard advances were Rs. 168.46 Crores in 2008 still increased Rs. 765.89 Crores in 2013. The doubtful assets also increased Rs. 190.83 Crores to Rs. 734.85 Crores from 2008 to 2013. Amount of loan assets are increasing every year but the percentage of standard advances is decreasing in 2013 than the percentage of 2008 . 
Table II Classification of Loan Assets of Private Sector Banks (In Crores)

\begin{tabular}{|l|l|l|l|l|l|l|}
\hline $\begin{array}{l}\text { Bank/Group } \\
\text { Year }\end{array}$ & \multicolumn{2}{|l|}{ Standard Advances } & \multicolumn{2}{l}{ Sub Standard Advances } & \multicolumn{2}{l}{ Doubtful Advances } \\
\hline $\begin{array}{l}\text { Private Sector } \\
\text { Bank }\end{array}$ & Amount & Percent & Amount & Percent & Amount & Percent \\
\hline 2008 & 4597.22 & 97.25 & 72.81 & 1.54 & 44.53 & 0.94 \\
\hline 2009 & 5031.87 & 96.75 & 105.27 & 2.02 & 50.18 & 0.96 \\
\hline 2010 & 5677.23 & 97.03 & 86.78 & 1.48 & 65.43 & 1.12 \\
\hline 2011 & 7149.78 & 97.55 & 44.00 & 0.60 & 107.36 & 1.46 \\
\hline 2012 & 8628.96 & 97.92 & 51.33 & 0.58 & 103.16 & 1.17 \\
\hline 2013 & 10266.73 & 98.09 & 58.54 & 0.56 & 110.69 & 1.06 \\
\hline
\end{tabular}

Source: (http://www.rbi.org.in/) [14]

Table II clearly shows that the advances of private sector banks from 2008 to 2013 . The advances are decreased from 97.25 percent to 96.75 percent in 2009 but it is increased continuously till 2013. In the other side the sub standard assets percentage increase from 2008 to 2009 but it is continuously decreased from 2009 to 2013.in 2009 it was 2.02 percent but it was just 0.56 percent in 2013. The amount of doubtful advances is still increasing from 2008 to 2013 but the percentage is changing in every year. In 2008 the doubtful assets were 0.94 percent but it was 1.46 percent in 2011 and 1.06 percent in 2013.

Compared to Private and Public sector banks NPAs level is more in case of substandard asset and doubtful asset. But in case of standard asset private sector banks remain high which shows a good position of private sector banks and also it show that they have adopted all necessary measures in order to avoid any account becoming NPAs. Public sector banks need to be more cautions while granting loan and also to avoid the occurrence of NPA in public sector banks [3].

Table III NPA in Private Sector Banks and Public Sector Banks from 2008-13

\begin{tabular}{|l|l|l|l|l|l|l|}
\hline \multirow{2}{*}{} & \multicolumn{2}{|l|}{ Year } & NPA in Private Sector Banks & \multicolumn{2}{l|}{ NPA in Public Sector Banks } \\
\cline { 2 - 7 } & Amount & NPA in SSI & $\begin{array}{l}\text { NPA in } \\
\text { Agriculture }\end{array}$ & Amount & NPA in SSI & $\begin{array}{l}\text { NPA in } \\
\text { Agriculture }\end{array}$ \\
\hline 2008 & 12976 & 651 & 1467 & 39750 & 5805 & 8268 \\
\hline 2009 & 16887 & 670 & 1441 & 43908 & 6984 & 5708 \\
\hline 2010 & 17384 & 1139 & 2023 & 57448 & 11537 & 8330 \\
\hline 2011 & 17971 & 1298 & 2172 & 71015 & 14340 & 14487 \\
\hline 2012 & 18300 & --- & --- & 112500 & --- & --- \\
\hline 2013 & 20000 & --- & --- & 155900 & -- & -- \\
\hline
\end{tabular}

Source: RBI, Report on Trend and Progress of Banking in India, various issues.

The table shows that the private sector banks and public sector bank NPA from 2011-12. In 2008 the total NPA in private sector was Rs. 12976 Crores but it is increased to Rs.17971 Crores in 2011 and Rs.20000 Crores in 2013. The table also shows the different sector NPA value like SSI and agriculture sector in private sector and public 
sector banks. In the other side the NPA value of public sector banks in 2008 were Rs. 39750 Crores but it is increased to Rs. 71015 Crores in 2011 and Rs. 155900 Crores in 2013.

\section{CONCLUSION}

The entire given table tells about the NPA value in different year. If we talking about the private sector NPA value than it show near about double amount of NPA in 2013 than 2008. It means the amount which is given to SSI and agriculture or any other sector by private sector bank or public sector banks that affects the value of profit and reputation of these banks. The agriculture sector in which Rs.1467 Crores amounts comes under NPA in 2008 but it is increased Rs.2172 Crores in 2011 means this sector is responsible for increasing value of NPA. It is also shows that the agriculture sector is not being able to pay the loan amount of different banks at the right time. But not only the agriculture sector but also the small scale industries did not pay the amount of bank's loan at the right time. In 2008 the balance of NPA in private sector banks of SSI was Rs.651 Crores but it is increased Rs.1298 Crores in 2011 and it is still increasing. In public sector bank NPA in 2008 was Rs. 8268 Crores but it is Rs.14487 Crores in 2011 in agriculture sector and if we talking about the SSI the total NPA were Rs.5805 Crores in 2008 but it increased Rs. 14340 Crores in 2011. The entire figure shows that the reason of increasing NPA value of banks is not the proper use of factors in agriculture and small scale industries and other sectors.

\section{REFERENCES}

[1] Balasubramaniam, C.S, "Non-Performing Assets and Profitability of commercial Banks in India: Assessment and Emerging Issues". National monthly Refereed Journal of Research in Commerce \& Management, 1(7), pp. 41-52, (2001).

[2] Das, S. \& Dutta, A, “A Study on NPA of Public Sector Banks in India”. IOSR Journal of Business and Management (IOSR-JBM), 16(11), pp. 75-83, 2014

[3] Joseph, A.L. \& Prakash, M, "A Study on Analyzing the Trend of NPA Level in Private Sector Banks \& Public Sector Banks". International Journal of Scientific and Research Publications, 4(7), pp.1-9, 2014.

[4] Kaur, H. \& Saddy, N, "A comparative Study of Non Performing Assets of Public and Private Sector Bank". International Journal of Research in Commerce and Management, 2(9), pp.82-89, 2011.

[5] Kumar, S.R, "A comparative Study of Public Sector Banks and Private C Sector Banks with Reference to Non-Performing Assets". International Journal of in Multidisciplinary and Academic Research (SSIJMAR), 4(4), pp.1-12, 2015.

[6] Mahajan, P, "Non-Performing Assets: A Study of Public, Private \& Foreign Sector Banks in India”. Pacific Business Review International, 7(1), pp.9-16, 2014.

[7] Rao,M. \& Patel, A, "A Study on Non Performing Assets Management with Reference to Public Sector Banks, Private Sector Banks and foreign Banks in India". Journal of management and Science, 5(1), pp.30-43, 2015.

[8] Satpal, "A Comparative study of Non Performing Assets in Public and Private sector Banks in the New Age of Technology". International Journal of Current Engineering and Technology, 4(4), pp. 2468-2475, 2014.

[9] Singh, J, "Recovery of NPAS in Indian Commercial Banks". International Journal of Transformations in Business Management, 2(3), pp.77-95, 2013.

[10] Srivastava, V. (2014), A Study on Non-Performing Assets of Indian Banks, GYANPRATHA-ACCMAN Journal of Management, 5(2), 110.

[11] RBI, Report on Trend and Progress of Banking in India, 2006-07, page 72-73.

[12] https://en.wikipedia.org

[13] http://www.rbi.org.in/ 